\title{
Prodigies of nature
}

\author{
J S Jenkins MD FRCP
}

J R Soc Med 2005;98:277-280

On 31 May 1764 the following notice appeared in the London Public Advertiser:

'At the Great Room in Spring Garden, near St James' Park, Tuesday June 5, will be performed a grand concert of vocal and instrumental music. For the benefit of Miss Mozart of eleven and Master Mozart of seven years of age, Prodigies of Nature; taking the opportunity of representing to the public the greatest prodigy that Europe or that human nature has to boast of. Everybody will be astonished to hear a child of such a tender age playing the harpsichord in such perfection - it surmounts all fantastic imagination and it is hard to express which is more astounding, his execution upon the harpsichord playing at sight or his own compositions.' 1

Even when we allow for Leopold Mozart's hyperboles and the fact that he deducted a year from his children's ages, young Wolfgang was clearly one of the great musical prodigies.

Prodigies have always been regarded with awe because they disobey the usual rules of childhood development. A study of their lives shows that various factors are involved in the determination of their extraordinary achievements. High ability may be linked to creativity but what is most easily measured is performance.

\section{THE DOMAINS OF A PRODIGY}

One definition of the term prodigy is a child who has achieved an appreciable measure of adult intellectual understanding in a particular field before he or she is out of the years devoted to secondary school education. Others have restricted the age to ten years. Whatever definition is used, a prodigy, unlike a normal child, is a precocious specialist in a particular field of endeavour. There are, however, few domains in which he or she is found. Music is the most common, followed by chess, mathematics and, to a much less extent, visual art. Music has provided many prodigies in addition to Mozart. Mendelssohn first appeared in concert at the age of nine and published his first piano quartet at thirteen. Chopin published two polonaises by the age of seven, and Liszt was already an accomplished concert

40 Hampstead Way, London NW11 7JL, UK

E-mail: john.jenkins6@which.net pianist by the age of twelve. In modern times Yehudi Menuhin is a well known example. In chess, great players are usually recognized early in life as being exceptional. Bobby Fischer, US champion at fifteen years old, was competing with grand masters at the age of six, and in 2002 Sergei Karajakin from the Ukraine was confirmed as being the youngest ever grand master at the age of twelve. The most remarkable mathematics prodigy of the present day is Ruth Lawrence who in 1985 entered Oxford University at the age of eleven, accompanied by her father who had tutored her, and graduated with a first class degree two years later. Of the few prodigies in visual art Pablo Picasso is the most notable.

There are reasons for the predominance of music. For a child to be recognized as a prodigy, his or her achievement must be easily observable very early, and even normal children show a sense of musical appreciation at six months old. ${ }^{2}$ For example, at this age infants will respond by turning towards the source when hearing Mozart minuets but not to the same pieces in which dissonants have replaced consonants. ${ }^{3}$ Thus, precocious musical ability can be readily assessed by well established criteria. In chess, and to some extent in mathematics, an early high degree of proficiency is readily noted whereas in fields such as science signs of exceptional talent in childhood may go unobserved since longer periods are required to reach a noticeably superior level of performance. Albert Einstein and Charles Darwin are often cited as geniuses in whom early high achievement was not apparent. Music, therefore, provides a good field for studying the complexity of factors that are responsible for the making of a prodigy and there can be no better example than the early life of Mozart.

\section{THE IMPORTANCE OF INTELLIGENCE}

It has sometimes been asserted that prodigies are simply the result of high intelligence combined with intensive training in a particular subject at an early age. In a much quoted study Cox assessed the childhood IQ of 301 geniuses from history, on the basis of authenticated behaviour or achievement compared with that of the average child. ${ }^{4}$ In the case of Mozart she assessed his IQ in early life as 160. Such individual specific ratings are highly questionable but the average IQ of all the gifted children she studied was 155 . 
The importance of general intelligence in every instance has been disputed in view of the phenomenon of the idiot savant ${ }^{5}$ - an individual of measured low IQ with remarkable ability in a limited field such as rapid mathematical calculation or performance on a musical instrument. An outstanding memory is a characteristic feature of many savants and this may compensate for a lack of general intelligence. But in music it is possible by way of long practice to achieve a high standard of play which is purely technical without the power of expression that is necessary for a truly great performance. Savants are rare and great achievement in a child is nearly always associated with high intelligence, but this is only one of the factors involved in making a prodigy. Children with a high IQ are many, prodigies are few.

\section{GENETIC FACTORS}

General intelligence is itself heritable to a great degree ${ }^{6}$ but high ability in a specific field is also required. Whether children can possess innate inherited talent has been much debated. ${ }^{7}$ In many instances the musical prodigy has a family with a musical background - either in the parents or in close relatives. The best known example of a musical family is that of the Bachs; during two centuries over seventy members before and after Johann Sebastian earned their living as musicians. Mozart's father Leopold was deputy Kapellmeister in Salzburg, a well-known composer and author of a widely used manual on violin playing. His daughter Nannerl was a very gifted harpsichord player as a child. Even with such family histories it is difficult to disentangle the genetic and environmental contributions since the family would provide very favourable conditions to excel in music. However, twin studies have shown that both musical ability ${ }^{8}$ and mathematical achievement ${ }^{9}$ have a substantial genetic component.

\section{THE FAMILY ENVIRONMENT}

The importance of the family environment in the production of a prodigy is undisputed. The parents may not necessarily be the first to appreciate the talent of their child but one parent is usually the driving force in the education of that child. In the case of Mozart the father, realizing his son was extraordinary, gave up his own musical career to devote himself to the children's education. After Wolfgang's death Nannerl wrote:

'In the fourth year of his age his father, for a game as it were, began to teach him a few minuets and pieces at the clavier. It was so easy for this child and for his father that he learnt a piece in an hour and a minuet in half an hour so that he could play it faultlessly and with the greatest delicacy and keeping exactly in time. He made such good progress that at the age of five he was already composing little pieces which he played to his father who wrote them down.' 10

His education became even more intensive and from the age of six he was taken on tours of Europe where he met and was instructed by the famous musical figures of the time, so that Leopold was able to say 'my boy knows in his eighth year what one would expect in a man of forty." ${ }^{11}$ While he was in London, Mozart, aged nine, was assessed by the eminent lawyer, amateur musician and Fellow of the Royal Society, Daines Barrington, who wrote:

'Happening to know that the little Mozart was much taken notice of by Manzoli, the famous singer, who came over to England in 1764, I said to the boy that I should be glad to hear an extemporary love song such as his friend Manzoli might choose in an opera. The boy on this (who continued to sit at his harpsichord) looked back with much archness, and immediately began five or six lines of a jargon recitative proper to introduce a love song... his execution was amazing considering that his little fingers could scarcely reach a fifth on the keyboard. His astonishing readiness, however, did not arise merely from great practice, he had a thorough knowledge of the fundamental principles of composition...'12

Sometimes the price of being a prodigy is that the family pressure can be intense - so much so that the child is not able to have a normal social life. As a child, Mozart met few children apart from his sister, his contacts outside the family being almost entirely adult musicians, and in later life he found it difficult to escape from the shackles of his father even to the extent of having to defy Leopold's attempt to interfere with his future marriage.

Yehudi Menuhin, a modern musical prodigy, was subjected to considerable parental control. At the age of eighteen a reporter asked his father if Yehudi was ever alone and the reply came 'No never. We are always with him to take care of him.' After he was married, whenever he developed a cold his mother insisted on treating him. ${ }^{13}$

\section{The importance of practice}

In music, sustained and early practice is essential for best performance. ${ }^{7,14}$ Ericsson reported that young violinists rated simply as excellent by their teachers had averaged as much as two hours' practice every day by the age of twentyone. ${ }^{7}$ In the case of musical prodigies not only do they start younger, at age five or less, but their motivation to practise is even greater. It is the combination of innate talent and long continued practice for many hours of the day from a very early age that is the mark of a prodigy. Their unusual 
determination, persistence, and motivation set them apart from children of similar age. Such attributes probably have a genetic origin. The same factors are present in prodigies relating to chess and mathematics, although in the latter domain practice usually starts later in childhood.

\section{The brain and musical ability}

Advances in imaging techniques by positron emission tomography and MRI have allowed examination of areas within the brain which are responsible for the appreciation of music and other activities. The primary auditory cortex is located in the region of Heschl's gyrus, running laterally and anteriorly in the superior temporal plane. From there the particular components of music appreciation involving rhythm, pitch, metre, melody and timbre are processed in many different areas, ranging from the prefrontal cortex to the precuneus of the parietal lobe, with much interconnection between the different networks activated. ${ }^{15}$ The brain has remarkable plasticity, particularly in the child, and the functional changes which occur are associated with structural alterations in the brain in young musicians. If musical practice is begun before the age of seven years, as in the case of prodigies, MRI shows that the frontal part of the corpus callosum becomes larger than that of non-musician controls. ${ }^{16}$ In a study of young string players an increase was found in the somatosensory areas of the brain representing the thumb and small finger of the left hand, again only if practice began before seven years. ${ }^{17}$

Musical prodigies frequently show the phenomenon of absolute pitch - the ability to identify a pitch accurately and rapidly without any external reference. It is generally uncommon, being present in only about $2 \%$ of a large group of amateur music students and professionals. ${ }^{18}$ In the case of Mozart the musician Johann Andreas Schachtner wrote:

"I had a very good violin which Wolfgang called the "butter violin" because of its soft and full tone. One day soon after his return from Vienna [just seven years of age] he played on it and could not find words to praise it highly enough; one or two days later I came to see him again and found him amusing himself with his own violin ... Finally he thought for a moment and said to me "Herr Schachtner, your violin is tuned half a quartertone lower than mine, if you tuned it as it was last time I played it." I laughed at this, but Papa [Leopold] knowing the extraordinary sense of pitch and memory of the child, asked me to fetch my violin and see if he was right. I did so, and he was right. ${ }^{10}$

That absolute pitch has a substantial genetic basis is shown by studies on siblings and twins. ${ }^{18}$ Anatomically, the possession of absolute pitch in right-handed individuals is associated with leftward asymmetry of that area in the temporal lobe known as the planum temporale, a well defined portion of the auditory cortex posterior to Heschl's gyrus. ${ }^{19}$ Further studies point to a reduction in the size of the right and only a marginal increase in the left planum temporale. ${ }^{20}$ In left-handed persons there is either no asymmetry or the right side is larger. Early musical training further increases the development of the leftward planum temporale asymmetry but there is a genetic component to the anatomy of the region since asymmetry, when it occurs, is already present in utero between the twenty-ninth and thirty-first week of gestation. ${ }^{21}$ The functional significance of these anatomical findings remains unknown.

\section{The future of a child prodigy}

Some chess prodigies later become grand masters and chess champions. Bobby Fischer became increasingly eccentric and since 1992 a warrant has been out for his arrest by the US Government for violating economic sanctions against Yugoslavia by playing a much-trumpeted World Championship there. The mathematical prodigy Ruth Lawrence is now a professor of mathematics, although she became estranged from her father and vowed never to bring up her own children in the way she herself had been educated. ${ }^{22}$ But because a child shows high ability in a particular domain at a preternaturally early age there is no certainty that performance at this level will continue into adult life. Much depends upon the child's persistence, motivation, and stamina, and there are some who rebel against the extreme pressures to succeed. A much quoted example is William James Sidis (1898-1944), an American mathematical prodigy who could read at the age of eighteen months, had written four books before his eighth birthday, and entered Harvard University at the age of eight. He was the first to write on black holes and other aspects of cosmology. But he could not deal with the pressures of his parents and the attention of the media. He renounced academic life and took up menial tasks such as running calculating machines; he died of cerebral haemorrhage at the age of forty-six. ${ }^{23}$

In music, many prodigies evolve into first-rate adult musicians and a very few become geniuses. Nannerl Mozart remained merely a good keyboard player but Wolfgang progressed apparently effortlessly from early life to adulthood as instrumentalist and composer. The art of composition requires mature appreciation of the components of music and is unusual at a young age, even in prodigies, but Mozart composed his first symphony at eight and his first full-length opera, La Finta Semplice, at twelve. 


\section{CONCLUSIONS}

Precocious talent in a restricted field such as music, chess or mathematics appears to be partly genetically determined. Environmental conditions, usually provided by the family, which ensure long intensive practice for many hours of the day are especially necessary and these are accompanied by unusual dedication to the pursuit of achievement in one so young. Occasionally the family pressures are intense and lead to difficulty in making normal childhood relationships or to abandonment of the pursuit.

The plasticity of the brain of a child which allows functional reorganization to occur is associated with structural alterations after long-term musical practice. Many prodigies, but not all, achieve high status in their professions in adult life. A very few, like Mozart, are regarded as geniuses.

\section{REFERENCES}

1 Public Advertiser 31 May 1764

2 Trehub SE. The developmental origins of musicality. Nature Neuroscience 2003;6:669-73

3 Trainor LJ, Heinmiller BM. The development of evaluative responses to music. Infant Behav Dev 1998;21:77-88

4 Cox C. The Early Mental Traits of Three Hundred Geniuses. Stanford: Stanford University Press, 1926:592-5

5 Treffert DA. The idiot savant: a review of the syndrome. Am J Psychiatry 1988;145:563-72

6 Brody N. Intelligence. New York: Academic Press, 1992

7 Ericsson KA, Krampe R, Tesch-Römer C. The role of deliberate practice in the acquisition of expert performance. Psychol Rev 1993;100:363-406
8 Coon H, Carey G. Genetic and environmental determinants of musical ability in twins. Behav Genet 1989;19:183-93

9 Walker SO, Petrill SA, Spinath FM, Plomin R. Nature, nurture and academic achievement: a twin study of teacher assessments of 7 year olds. Br J Educ Psychol 2004;74:323-42

10 Deutsch OE. Mozart: a Documentary Biography, 3rd edn. London: Simon \& Schuster, 1990

11 Anderson E. The letters of Mozart and his Family, 3rd edn. London: Macmillan, 1989:48-9

12 Barrington D. An account of a very remarkable young musician. Phil Trans R Soc 1770;60:54-64

13 Palmer T. Menuhin: a Family Portrait. London: Faber \& Faber, 1991;37:190

14 Sloboda JA, Howe MJA. Biographical precursors of musical excellence; an interview study. Psychol Music 1991;19:110-20

15 Warren JD. Variations in the musical brain. J R Soc Med 1999;92: 571-5

16 Schlaug G, Jaencke L, Huang Y, Steinmetz H. Increased corpus callosum size in musicians. Neuropsychologia 1995;33:1047-55

17 Elbert TC, Pantev C, Wienbruch C, Rockstroh B, Taub E. Increased cortical representation of the fingers of the left hand in string players. Science $1995 ; 270: 305-7$

18 Gregersen PK. Instant recognition: the genetics of pitch perception. Am J Hum Genet 1998;62:221-3

19 Schlaug G, Jaencke L, Huang Y, Steinmetz H. In vivo evidence of structural brain asymmetry in musicians. Science 1995;267: 699-701

20 Keenan JP, Thangaraj V, Halpern AR, Schlaug G. Absolute pitch and planum temporale. Neuroimage 2001;14:1402-8

21 Preiss S, Jaencke L, Schmitz-Hillebrecht J, Steinmetz H. Child age and planum temporale asymmetry. Brain Cogn 1999;40:441-52

22 Sunday Mirror 4 June 2000

23 Wallace A. The Prodigy: a Biography of William James Sidis, America's Greatest Child Prodigy. New York: EP Dutton, 1986 